\title{
Characteristics of Young Adults Sentenced with Juvenile Sanctions in the Netherlands
}

\author{
Lise Prop, André van der Laan, Charlotte Barendregt \& Chijs van Nieuwenhuizen*
}

\section{Abstract}

Since 1 April 2014, young adults aged 18 up to and including 22 years can be sentenced with juvenile sanctions in the Netherlands. This legislation is referred to as 'adolescent criminal law' (ACL). An important reason for the special treatment of young adults is their over-representation in crime. The underlying idea of $A C L$ is that some young adult offenders are less mature than others. These young adults may benefit more from pedagogically oriented juvenile sanctions than from the deterrent focus of adult sanctions. Little is known, however, about the characteristics of the young adults sentenced with juvenile sanctions since the implementation of ACL. The aim of this study is to gain insight into the demographic, criminogenic and criminal case characteristics of young adult offenders sentenced with juvenile sanctions in the first year after the implementation of ACL. A cross-sectional study was conducted using a juvenile sanction group and an adult sanction group. Data on 583 criminal cases of young adults, sanctioned from 1 April 2014 up to March 2015, were included. Data were obtained from the Public Prosecution Service, the Dutch Probation Service and Statistics Netherlands. The results showed that characteristics indicating problems across different domains were more prevalent among young adults sentenced with juvenile sanctions. Furthermore, these young adults committed a greater number of serious offences compared with young adults who were sentenced with adult sanctions. The findings of this study provide support for the special treatment of young adult offenders in criminal law as intended by $A C L$.

Keywords: young adult offenders, juvenile sanctions for young adults, juvenile criminal law, psychosocial immaturity

\section{Introduction}

On 1 April 2014, adolescent criminal law (ACL, in Dutch referred to as Adolescentenstrafrecht) was implemented in the Netherlands. ACL is not a separate type of criminal law, but refers to several legislative

Lise Prop is researcher at the Research and Documentation Centre (WODC), Den Haag, the Netherlands. André van der Laan is senior researcher at the Research and Documentation Centre (WODC), Den Haag, the Netherlands. Charlotte Barendregt is senior advisor at the Health and Youth Care Inspectorate, Utrecht, the Netherlands. Chijs van Nieuwenhuizen is professor at Tilburg University, and treatment manager at the Centre for Child and Adolescent Psychiatry in Eindhoven, the Netherlands. changes made in the Dutch Criminal Code (DCC). In general, in the Netherlands, 12-17-year-old offenders are sentenced with juvenile sanctions, while offenders aged 18 and over are sentenced according to adult criminal law. One of the legislative changes made in the context of ACL concerns the increase in the age limit for application of Article 77c of the DCC. Depending on two legal conditions, offender's personal characteristics and the circumstances under which an offence was committed, it is now possible to sentence young adult offenders, aged 18 up to and including 22 years at the time of committing an offence, with juvenile sanctions. The aim of ACL is to create more flexibility in the sanctioning of offenders around the age of 18. The main focus of ACL is the special treatment of young adult offenders, in order to increase resocialisation and reduce recidivism. ACL seeks to achieve this using a tailor-made approach in sanctioning.

The attention to the need for special treatment of young adult offenders in the criminal justice system is not new. Since the 1950s, it has been discussed that young adult offenders could be dealt with more effectively in the criminal justice system, and several attempts have been made to achieve special treatment for this group of offenders. ${ }^{1}$ Since 1965 , young adults - aged 18 up to and including 20 - can be sentenced according to juvenile criminal law. In practice, it turned out that this option was hardly used. ${ }^{2}$ At the beginning of the 21 st century, academics and professionals expressed interest in raising the age limit for the sentencing of young adults according to juvenile criminal law. ${ }^{3}$ This renewed interest was driven by scientific insights into brain

1. Commissie-Overwater, 'Rapport van de commissie ingesteld met het doel van advise tedienen over de vraag in welke richting het rijkstuchten opvoedingswezen en in verband daarmede het kinderstrafrecht zich zullen moeten ontwikkelen' (1951); Commissie-De-Jong, 'Rapport betreffende de strafrechtelijke behandeling van jeugdige personen' (1953); A.M. Van der Laan, M.G.C.J. Beerthuizen and C.S. Barendregt, 'Juvenile Sanctions for Young Adults in the Netherlands: A Developmental Perspective', European Journal of Criminology 1 (2019) Epub ahead of print 13 June. DOI: 10.1177/1477370819854163; E.P. Schmidt, S.E. Rap and T. Liefaard, 'Young Adults in the Justice System: The Interplay between Scientific Insights, Legal Reform and Implementation in Practice in The Netherlands', Youth Justice 1 (2020) Epub ahead of print 6 January. DOI: 10.1177/1473225419897316; P.H. Van der Laan et al., 'Offending and Justice Response at the Juvenile-Adult Interface', in R. Loeber, M. Hoeve, N.W. Slot and P.H. Van der Laan (eds.), Persisters and Desisters in Crime from Adolescence into Adulthood. Explanation, Prevention and Punishment (2012) 201.

2. A.M. Van der Laan and H. Goudriaan, 'Monitor Jeugdcriminaliteit. Ontwikkelingen in de jeugdcriminaliteit 2000 tot 2017' (2018).

3. Van der Laan et al. (2019), above n. 1 
development and begged the question of whether young adults can be treated as adults in the criminal justice system. ${ }^{4}$ In 2011, the Secretary of State for Security and Justice introduced a proposal for legislative changes to increase the maximum age for sentencing young adults according to juvenile criminal law. In 2013, this proposal was approved, and this legislative change became known as ACL.

An important reason for focusing on offenders around the age of 18 is their over-representation in crime. ${ }^{5}$ As the age-crime curve demonstrates, there is an increase in criminal behaviour during adolescence, with a peak around the late teens (16-20 years), followed by a gradual decrease starting in the early twenties. ${ }^{6}$ In general, adolescence is seen as a period of normal development between childhood and adulthood that is characterised by biological, psychological, emotional, social and cognitive changes. ${ }^{7}$ Adolescence is also a period of increased experimentation, heightened sensitivity to peer influences and involvement in risky behaviour. ${ }^{8}$ In the past decades, attention has increasingly been paid to the role of the immature social, cognitive, psychological and emotional development of adolescents and young adults as a possible explanation for their over-representation in crime statistics. ${ }^{9}$

Several studies show that the immature psychosocial development of adolescents and young adults can be related to risk-taking and delinquent behaviour. ${ }^{10}$ For example, the ability to control impulses, consider the implications of one's actions, resist peer influences and delay gratification in order to achieve longer term goals are functions that may not be entirely under an individual's control owing to his or her psychosocial immaturity. ${ }^{11}$ Research also indicates that one of the reasons for

4. Van der Laan et al. (2019), above n. 1; Schmidt et al., above n. 1.

5. Van der Laan et al. (2012), above n. 1; D.P. Farrington, 'Age \& Crime', in M. Tonry and N. Morris (eds.), Crime and Justice. An Annual Review of Research (1986) 189.

6. Farrington, above n. 5 .

7. R.J. Bonnie and E.S. Scott, 'The Teenage Brain: Adolescent Brain Research and the Law', 22(2) Current Directions in Psychological Science 158 (2013).

8. C. Bryan-Hancock and S. Casey, 'Psychological Maturity of At-Risk Juveniles, Young Adults and Adults: Implications for the Justice System', 17(1) Psychiatry, Psychology and Law 57 (2010); A. Galván, 'The Teenage Brain Sensitivity to Rewards', 22(2) Current Directions in Psychological Science 88 (2013); E.S. Scott and L. Steinberg, 'Adolescent Development and the Regulation of Youth Crime', 18(2) The Future of Children 15 (2008).

9. Bonnie and Scott, above n. 7; L. Steinberg, 'The Influence of Neuroscience on US Supreme Court Decisions about Adolescents' Criminal Culpability', 14 Nature Reviews Neuroscience 513 (2013); K.C. Monahan, L. Steinberg, E. Cauffman and E.P. Mulvey, 'Trajectories of Antisocial Behavior and Psychosocial Maturity from Adolescence to Young Adulthood', 45(6) Developmental Psychology 1654 (2009).

10. E. Cauffman, C. Cavanagh, S. Donley and A.G. Thomas, 'A Developmental Perspective on Adolescent Risk-Taking and Criminal Behavior', in A.R. Piquero (ed.), The Handbook of Criminological Theory (2015) 100; K.C. Monahan, L. Steinberg and A.R. Piquero, 'Juvenile Justice Policy and Practice: A Developmental Perspective', 44 Crime and Justice 577 (2015).

11. Monahan et al. (2009), above n. 9; H.L. Chung, M. Little and L. Steinberg, 'The Transition to Adulthood for Adolescents in the Juvenile Justice System: A Developmental Perspective', in D.W. Osgood, E.M. Foster, C. Flanagan and G.R. Ruth (eds.), The John D. and Catherine T. desisting from crime is that young adults mature out of antisocial behaviour. ${ }^{12}$

Maturity, however, is an elusive construct, which makes it susceptible to different interpretations. ${ }^{13}$ Maturity can, for instance, be defined as the level of development of different brain structures, the nature and degree of young adults' planning and foresight, behavioural intentions, their understanding of norms and morals, or decision-making patterns. ${ }^{14}$ Maturity is also characterised by self-reflective thoughts, future-orientation, self-regulation and the ability to oversee the (long-term) consequences of behaviour. ${ }^{15}$ Others see maturity more from a social developmental perspective, focusing on the autonomous development of young adults with regard to social relations, education, employability or finance. ${ }^{16}$ In order to understand the relationship between maturity and delinquency during adolescence, Steinberg and Cauffman proposed a mode ${ }^{17}$ that suggests that during adolescence and early adulthood three aspects of psychosocial maturity develop. ${ }^{18}$ These three factors of psychosocial maturity are (1) responsibility, (2) perspective and (3) temperance. All three affect an individual's decision-making abilities and behaviour. ${ }^{19}$ Responsibility is defined as the ability to act autonomously and independently, being self-reliant and forming one's identity. Perspective is defined as the ability to understand and consider the point of view of others and to analyse decisions within a broader context. Temperance is defined

MacArthur Foundation Research Network on Transition to Adulthood. On Your Own Without a Net: The Transition to Adulthood for Vulnerable Populations (2005) 68.

12. Monahan et al. (2009), above n. 9; Monahan et al. (2015), above n. 10; Bonnie and Scott, above n. 7; S.J. Blakemore and S. Choudhury, 'Development of the Adolescent Brain: Implications for Executive Function and Social Cognition', 47 Journal of Child Psychology and Psychiatry 296 (2006).

13. L. Steinberg and E. Cauffman, 'Maturity of Judgement in Adolescence Psychosocial Factors in Adolescent Decision Making', 20(3) Law and Human Behavior 249 (1996); D. Prior et al., 'Maturity, Young Adults and Criminal Justice: A Literature Review', University of Birmingham (2011).

14. E.A. Crone and R. Dahl, 'Understanding Adolescence as Period of Social-affective Engagement and Goal Flexibility', 13 Nature Reviews. Neuroscience 636 (2012); Bonnie and Scott, above n. 7; A.-M.R. Iselin, J. DeCoster and R.T. Salekin, 'Maturity in Adolescent and Young Adult Offenders: The Role of Cognitive Control', 6 Law and Human Behavior 455 (2009).

15. Bonnie and Scott, above n. 7; K.C. Monahan, L. Steinberg, E. Cauffman and E.P. Mulvey, 'Psychosocial (Im)maturity from Adolescence to Early Adulthood: Distinguishing Between Adolescence-Limited and Persisting Antisocial Behavior', 25 Development and Psychology 1093 (2013); S.B. Johnson, R.W. Blum and J.N. Giedd, 'Adolescent Maturity and the Brain: The Promise and Pitfalls of Neuroscience Research in Adolescent Health Policy', 45(30) Journal of Adolescent Health 216 (2009); Iselin et al., above n. 14.

16. J.M. Hill, A.A.J. van der Geest, V.R. Branje, S.J.T. Hale and W.H.J. Meeus, 'Growing Up: How Personality Maturation and Adult Role Transitions Relate to Desistance from Delinquency', in J.M. Hill (ed.), On the Road to Adulthood. Delinquency and Desistance in Dutch Emerging Adults (2017) 100.

17. Steinberg and Cauffman, above n. 13.

18. Monahan et al. (2015), above n. 10.

19. Steinberg and Cauffman, above n. 13; E. Cauffman and L. Steinberg, ' $(\mathrm{Im})$ maturity of Judgment in Adolescence: Why Adolescents May be Less Culpable than Adults', 18(6) Behavioral Sciences \& the Law 741 (2000) 
as the ability to limit impulsiveness, to evaluate consequences before acting and to control aggressive responses and risk-taking behaviour. ${ }^{20} \mathrm{In}$ an attempt to provide a description for legal practice, Steinberg argued that immaturity can be described as functions that may not be entirely under an individual's control. ${ }^{21}$ Some young adults do not seem to have full control over important functions such as the inhibition of socially unacceptable behaviour and impulse control. ${ }^{22}$ During adolescence and young adulthood, individual variability exists in the level and rate of these psychosocial functions. However, despite individual variability in the level of maturity, in general, young adults are not fully mature until their mid-twenties. $^{23}$

Central to ACL is the question of the maturity of young adult offenders. Young adult offenders with an immature emotional, social, moral and/or intellectual development are eligible for sentencing with juvenile sanctions. According to the policy theory of ACL, juvenile sanctions are, owing to their pedagogical perspective, more adequate than adult sanctions in increasing resocialisation and reducing recidivism among immature young adult offenders. ${ }^{24}$ In the pre-trial phase of ACL, advisory reports are produced by forensic experts, considering offenders' personal characteristics (e.g. their level of immaturity). With the help of these advisory reports, judges are able to apply tailor-made juvenile sanctions. ${ }^{25}$

With the introduction of ACL, the pedagogical approach of the juvenile justice system has become available to a wider range of young adults. To achieve this, extensive assessment of the offender's personal characteristics during the pre-trial phase by forensic experts is necessary. According to the Explanatory Memorandum of ACL, young adult offenders who demonstrate immature development, offenders of serious offences, high-frequency offenders and vulnerable young adults are all eligible for juvenile sanctions. ${ }^{26}$ However, the characteristics of young adults who are sentenced with juvenile sanctions remain unknown. The aim of this study is to gain insight into the characteristics of young adults who were sentenced in the first year after the introduction of ACL. The main research question is, what are the differences in demographic, criminogenic and criminal case characteristics between 18 to 22-year-olds who were sentenced with juvenile sanctions and between 18 to 22 -year-olds who were sentenced with adult sanctions in the first year after the introduction of ACL?

\section{Method}

A cross-sectional study was conducted to examine the demographic, criminogenic and criminal case characteristics of young adults sentenced with juvenile sanctions. Data concerning demographic characteristics were obtained from Statistics Netherlands and the Dutch Public Prosecution Service (hereafter referred to as Public Prosecution). Criminogenic and criminal case characteristics were registered in the context of the criminal trial; these data were retrospectively collected from the Public Prosecution and the Dutch Probation Service (hereafter referred to as Probation Service).

\subsection{Study Sample}

With the introduction of ACL, the selection of young adult offenders during the pre-trial phase is emphasised, and the Public Prosecutor (hereafter referred to as prosecutor) can select cases that qualify for juvenile sanctions in an early phase. According to Article 63 of the Code of Criminal Procedure (CCP), the prosecutor is provided with the possibility to state his intention to request the application of juvenile criminal law at the beginning of the criminal justice process. The decision as to whether the prosecutor is intended to request the application of juvenile criminal law is based on an early screening by the prosecutor and, in the case of pre-trial detention, on an early forensic report by the Probation Service. ${ }^{27}$ To assist prosecutors in their decision, they are provided with four indications regarding the eligibility of young adult offenders for juvenile sanctions. These four indications are as follows: (1) does the offender attend school, (2) does the offender live with his parents, (3) does the offender receive some form of support in cases of (mild) mental retardation and (4) is the offender susceptible to treatment. ${ }^{28}$ When the prosecutor is intended to request the application of Article $77 \mathrm{c}$ of the DCC, young adults, as with juveniles, will be placed in a young offenders' institution during their pre-trial detention, and the investigative judge has to decide whether suspension of pre-trial detention is possible. ${ }^{29}$ Then, during the pre-trial phase, probation officers are asked to prepare a forensic report, intended to advise the prosecutor and the judge. ${ }^{30}$ In their forensic reports, probation officers focus on the risk of recidivism and which treatment could be suitable for the young adult offender. In the case of serious offences, or when there are indications of psychopathology, forensic experts of The Netherlands Institute of Forensic Psychiatry and Psychology (NIFP) can be requested to give
Steinberg and Cauffman, above n. 13; Bryan-Hancock and Casey, above n. 8; Prior et al., above n. 13.

21. Steinberg, above n. 9.

22. Monahan et al. (2015), above n. 10; Steinberg, above n. 9

23. Monahan et al. (2015), above n. 10.

24. Van der Laan et al. (2019), above n. 1.

25. Ibid.

26. Parliamentary Documents II, 2012/13, 33498, no. 3, at 2, 6, 22.
Sichtlijn en kader strafvorc inclusief strafmaten Halt, (2014). [Government Gazette no. 8284, Directives regarding criminal processing of juveniles and adolescents] Although the list of indications is intended to be used in the preselection of young adult offenders, in practice it turned out that prosecutors are relying primarily on their experience and the seriousness of the offence (see also Van der Laan et al., 2019).

29. Art. 493 CCP.

30. Art. 63 (6) CCP 
(additional) advice about the young adult offender. At this point, a further selection of young adults qualifying for juvenile sanctions is made. When a forensic report gives cause, it is possible to adjust the intention of the prosecutor to request the application of juvenile criminal law or adult criminal law. Although the judge takes the final decision as to whether or not a young adult will be sentenced according to juvenile criminal law, the prosecutor has an important role in the selection of cases during the pre-trial phase.

In order to investigate the characteristics of young adults sentenced with juvenile sanctions, two groups of young adults were selected: (1) 18-22-year-old offenders with a case registered between 1 April 2014 and 1 April 2015, resulting in a juvenile sanction (i.e. the JS group) and (2) 18-22-year-old offenders with a case registered in 2015, resulting in an adult sanction (i.e. the AS group). Both groups were selected from the official registration system of the Public Prosecution, Rhapsody Central (RAC-min), which contains data on all criminal cases handled by district courts in the Netherlands. The following inclusion criteria were used. First, offenders had to be aged between 18 and 22 years old at the time of committing the offence. Second, in cases of multiple registered offences, at least one offence had to be committed after the offender had turned 18 years old. Third, at least one of the offences had to be committed between 1 April 2014 and 31 December 2015. Only criminal cases that were settled by district courts were selected. Appeal cases and those cases settled by the Public Prosecution were excluded.

A total of $n=403$ criminal cases of young adults who were sentenced with juvenile sanctions were selected for the JS group. The AS group consisted of a random selection of all cases in which young adults were sentenced according to adult criminal law $(n=10.872)$. A random sample stratified by age at the time of committing the offence of $n=150$ criminal cases was selected. The number of 21- and 22-year-olds was relatively small in absolute numbers; the 21- and 22-year-olds were therefore oversampled by a factor of $3(n=45$ instead of $n=15$ ). This resulted in a total of $n=180$ criminal cases of young adults who were sentenced according to adult criminal law selected for the AS group. A comparison of the JS group and AS group shows a significant difference in mean age. The JS group is characterised by a significantly lower mean age at the time of the offence compared with the AS group $(\mathrm{M}=18.8 ; \mathrm{SD}=1.1 ; \mathrm{M}=19.3 ; \mathrm{SD}=1.4 ; \mathrm{t}(581)=$ $-4.1, p<0.05)$. The JS group consisted of significantly more 18-year-olds and fewer 21- and 22-year-olds $\left(\chi^{2}(\mathrm{df}=4)=24.9, p<0.05\right)$. In the JS group the majority of young adults $(52.4 \%)$ was 18 years old at the time of committing the offence, followed by 19 years old $(24.8 \%)$, whereas the AS group, because of the oversampling, consisted of relatively more $21(16.7 \%)$ and 22-year-olds $(8.3 \%)$. The differences between the JS group and the AS group are described without differentiating in age categories. Two arguments underlie this choice. First, because of the small numbers it was not possible to analyse differences between both groups for all separate age categories. Second, in the introduction it is stated that despite individual variability in the level of maturity, in general, young adults are not fully mature until their mid-twenties.

In order to examine whether the AS group was representative for the population of young adults sentenced according to adult criminal law, the available criminal case characteristics of the population and the sample were compared. The AS group and population showed differences in respect of two criminal case characteristics, namely age and type of offence, as would be expected given the stratification by age and oversampling of 21- and 22-year-olds in the AS group. While the population consisted of $16.0 \% 18$-year-olds and $21.4 \%$ of both 21- and 22-year-olds, in the AS group $42.2 \%$ were 18 years old, $16.7 \%$ were 21 years old and $8.3 \%$ were 22 years old. Thus, the number of 21- and 22year-olds was relatively low compared with the population. Regarding the type of offence, within the population almost twice as many traffic offences were committed compared with within the sample $(10.7 \%$ in the population and $5.6 \%$ in the sample). A possible explanation for the relatively low percentage of traffic offences in the AS group is the over-representation of 18 year olds; these young adults are less likely to have a driver's licence compared with older young adults. No differences were found between the groups on the type of sanction imposed.

\subsection{Measures}

The characteristics of young adults sentenced with juvenile sanctions measured in this study were divided into three categories: (1) demographic characteristics, (2) criminogenic characteristics and (3) criminal case characteristics (see Table 1). Three data sources were used to identify these characteristics (see Table 2).

\subsubsection{Demographic Characteristics}

Data regarding demographic characteristics (ethnicity, education, socio-economic status and accommodation) were requested from the Social Statistics Files $(\mathrm{SSB})^{31}$ of Statistics Netherlands and from RAC-min (age). Data on $n=385$ individuals from the JS group and $n=$ 147 individuals from the AS group were available.

\subsubsection{Criminogenic Characteristics: OASys}

The Dutch version of the Offender Assessment System (OASys, in Dutch: RISc) was used to gain insight into criminogenic characteristics (see Table $1^{32}$ The OASys is a structured assessment tool used to assess offending related risks and needs associated with criminal activities and reconviction. It consists of both static (e.g.

31. F.M. Bakker, J. Van Rooijen and L. Van Toor, 'The System of Social Statistical Datasets of Statistics Netherlands: An Integral Approach to the Production of Register-based Social Statistics', 30 Statistical Journal of the IAOS 411 (2014).

32. A. Vinke et al., 'RISC: Recidive Inschattingsschalen. Handleiding' (Adviesbureau Van Montfoort, Woerden, 2013); P. Howard, 'The Offender Assessment System: An Evaluation of the Second Pilot' (Home Office, United Kingdom, 2006). 
criminal history) and dynamic factors (e.g. drug misuse). ${ }^{33}$ The OASys consists of 12 items; (1-2) criminal history and (current) offence analysis (e.g. whether the person committed an offence before the age of 18 , the type of offence and the seriousness of the offence), (3) housing and living arrangements (e.g. is the person homeless, are his/her living arrangements unstable, does he live in a high-crime neighbourhood), (4) education, training and employability (e.g. is the person unemployed or does he/she have suitable work), (5) financial management and income (e.g. does the person have a poor financial situation, does he/she have debts), (6) relationships with partner, family and relatives (e.g. is there a lack of secure attachment or a lack of a prosocial role model, are the person's family relationships of poor quality), (7) lifestyle and associates (e.g. does the person have criminal friends, does he/she takes advantage of others), (8-9) drug and alcohol misuse (e.g. is the person addicted to drugs and/or alcohol), (10) emotional well-being (e.g. does the person repeatedly lie and cheat, show aggressive behaviour, does the person have reduced or no sense of guilt and shame), (11) thinking, behaviour and skills (e.g. does the person show cognitive deficits, show a lack of social skills and/or problems with his/her impulse control, does the person show a lack of empathy) and (12) attitudes (e.g. does the person have a pro-criminal attitude). The OASys scores were obtained from the Integral Probation Information System (IRIS), the database of the Probation Service. OASys scores for $n=233(57.8 \%)$ of the offenders in the JS group and $n=34(18.8 \%)$ of the offenders in the AS group were available.

\subsubsection{ACL Screening Tool}

With the introduction of ACL, probation officers are explicitly asked whether sentencing with juvenile sanctions is advised. To assist probation officers, an 'ACL screening tool' (in Dutch: Wegingskader Adolescentenstrafrecht) was developed. ${ }^{34}$ The ACL screening tool is not a decision-making tool but is intended as a guideline to gain insight into indications and contraindications for sanctioning young adults according to juvenile criminal law. It helps probation officers to structure their thoughts in order to come up with their advice regarding the type of criminal law. The ACL screening tool offers two indications and four contraindications for sanctioning young adult offenders with juvenile sanctions (see Table 1). These indications and contraindications consist of different items for which the probation officer can indicate whether these items apply to the

33. J. Bonta and D.A. Andrews, Risk-Need-Responsivity Model of Offender Assessment and Rehabilitation (2007).

34. W. Buysse and S. Scherders, Bruikbaarheid van het wegingskader ASR (2015) young adult offender. There is no ranking in items within the indications and contraindications. Based on the different items, a general conclusion is made up for each indication and contraindication. Indications for a juvenile sanction are: (1) capacity to instigate behaviour change (i.e. having a mild mental retardation, is not able to oversee long-term consequences of his behaviour, can hardly organise his own behaviour, is acting impulsively, demonstrates childish behaviour and is sensitive to peer influences) and (2) pedagogical possibilities (i.e. pedagogical approach is possible, pedagogical approach is necessary, continuing school attendance is necessary, actively participates in family, family-oriented assistance is necessary, dependency relationship with parent(s)/ caregiver(s), is susceptible to social, emotional or practical support by adults, current threat of neglect or abuse, needs a group-oriented living environment). Contraindications for juvenile sanctions are: (3) criminal history (i.e. the person has a persistent criminal career, previously imposed juvenile sanctions failed, has previously had a juvenile treatment order, and adult criminal law sanction is needed for long-term security of society), (4) criminal lifestyle (i.e. chosen criminal lifestyle, is proud of criminal activities, lives in a criminal environment and does not respect the judicial authorities), (5) psychopathy traits (i.e. demonstrates psychopathy traits, exhibits antisocial behaviour and uses others for own purposes) and (6) pedagogical impossibilities (i.e. no positive parental influence, the person has a negative influence on other juvenile delinquents). ACL screening tool scores were available for $n=167$ (41.4\%) offenders in the JS group and $n=31(17.2 \%)$ in the AS group.

\subsubsection{Criminal Case Characteristics}

Furthermore, data regarding criminal cases (e.g. type of offence and type of sanction) were obtained from RACmin and were available for both the total JS group $(n=$ $403)$ and AS group $(n=180)$.

\subsection{Data Analyses}

Differences between the JS group and AS group were tested using Chi-square tests. To minimise the problem of multiple comparisons due to multiple univariate analyses a modified Hochberg procedure was used. ${ }^{35}$ Where significant differences were found, a post-hoc test was conducted.

When assumptions for conducting a Chi-square test were violated Fisher's Exact Test, which is suitable for $2 \times 2$ cross tables, was conducted. The level of significance was set at $p<0.05$, tested one-sided. Data analyses were performed using SPSS 21 (Statistical Package for the Social Sciences).

35. D.M. Rom, 'An Improved Hochberg Procedure for Multiple Tests of Significance', 66 British Journal of Mathematical and Statistical Psychology 189 (2013) 
Table $1 \quad$ Measured characteristics and description for each domain

\begin{tabular}{|c|c|c|c|}
\hline Domain & Characteristic & Explanation & Categories \\
\hline \multirow[t]{7}{*}{ Demographic } & Age & $\begin{array}{l}\text { Age at time of } \\
\text { committing the } \\
\text { offence }\end{array}$ & $18 / 19 / 20 / 21 / 22$ \\
\hline & Ethnicity & $\begin{array}{l}\text { What is the eth- } \\
\text { nicity of the } \\
\text { offender (accord- } \\
\text { ing to the defini- } \\
\text { tion of Statistics } \\
\text { Netherlands) }\end{array}$ & Dutch/Moroccan/Turkish/Surinam/Dutch Antilles/other \\
\hline & Accommodation & $\begin{array}{l}\text { Living situation } \\
\text { at time of com- } \\
\text { mitting the } \\
\text { offence }\end{array}$ & Independent/with parents/with one parent/institutionalised/other \\
\hline & Education & $\begin{array}{l}\text { Was the young } \\
\text { adult attending } \\
\text { education at the } \\
\text { time of commit- } \\
\text { ting the offence? }\end{array}$ & Yes/no \\
\hline & & $\begin{array}{l}\text { Highest level of } \\
\text { education com- } \\
\text { pleted at time of } \\
\text { committing the } \\
\text { offence }\end{array}$ & Community college and higher/secondary/primary/unknown \\
\hline & & $\begin{array}{l}\text { Highest level of } \\
\text { education atten- } \\
\text { ded at time of } \\
\text { committing the } \\
\text { offence }\end{array}$ & Community college and higher/secondary/primary/unknown \\
\hline & $\begin{array}{l}\text { Socio-economic } \\
\text { status }\end{array}$ & $\begin{array}{l}\text { What is the } \\
\text { socio-economic } \\
\text { status of the } \\
\text { offender at time } \\
\text { of committing } \\
\text { the offence? }\end{array}$ & Employed/unemployment benefits/student/unemployed/unknown \\
\hline
\end{tabular}


Table $1 \quad$ Measured characteristics and description for each domain

\begin{tabular}{|c|c|c|c|}
\hline Domain & Characteristic & Explanation & Categories \\
\hline \multirow[t]{2}{*}{ Criminogenic } & $\begin{array}{l}\text { OASys items } \\
1-12\end{array}$ & $\begin{array}{l}\text { 1-2. Criminal his- } \\
\text { tory and (cur- } \\
\text { rent) offence } \\
\text { analysis; } 3 . \text { Hous- } \\
\text { ing and living; } 4 . \\
\text { Education, train- } \\
\text { ing and employa- } \\
\text { bility; } 5 \text {. Financial } \\
\text { management and } \\
\text { income; } 6 \text {. Rela- } \\
\text { tionships with } \\
\text { partner, family } \\
\text { and relatives; } 7 . \\
\text { Lifestyle and } \\
\text { associates; } 8 . \\
\text { Drug misuse; } 9 . \\
\text { Alcohol misuse; } \\
\text { 10. Emotional } \\
\text { well-being; } 11 . \\
\text { Thinking, behav- } \\
\text { iour and skills; } \\
\text { 12. Attitudes }\end{array}$ & No risk factor/risk factor \\
\hline & $\begin{array}{l}\text { Conclusion } \\
\text { according to } \\
\text { OASys }\end{array}$ & $\begin{array}{l}\text { Likelihood of } \\
\text { recidivism }\end{array}$ & Low-moderate/high-very high/no total risk assessment \\
\hline \multirow[t]{3}{*}{$\begin{array}{l}\text { Adolescent crim- } \\
\text { inal law screen- } \\
\text { ing tool }\end{array}$} & Indications & $\begin{array}{l}\text { 1. Capacity to } \\
\text { instigate behav- } \\
\text { iour change; } 2 \text {. } \\
\text { Pedagogical pos- } \\
\text { sibilities }\end{array}$ & $\begin{array}{l}\text { Indications for sentencing with juvenile sanction/no indications for sen- } \\
\text { tencing with juvenile sanction }\end{array}$ \\
\hline & Contraindications & $\begin{array}{l}\text { 3. Criminal histo- } \\
\text { ry; } 4 \text {. Criminal } \\
\text { lifestyle; } 5 \text {. Psy- } \\
\text { chopathy traits; } \\
\text { 6. Pedagogical } \\
\text { impossibilities }\end{array}$ & $\begin{array}{l}\text { Contraindication for sentencing with juvenile sanction/no contraindica- } \\
\text { tion for sentencing with juvenile sanction }\end{array}$ \\
\hline & $\begin{array}{l}\text { Conclusion Ado- } \\
\text { lescent criminal } \\
\text { law screening } \\
\text { tool }\end{array}$ & $\begin{array}{l}\text { Are there indica- } \\
\text { tions for sentenc- } \\
\text { ing the offender } \\
\text { with a juvenile } \\
\text { sanction? }\end{array}$ & $\begin{array}{l}\text { Indications for sentencing with juvenile sanction/no indications for sen- } \\
\text { tencing with juvenile sanction/no conclusive advice }\end{array}$ \\
\hline
\end{tabular}


Table $1 \quad$ Measured characteristics and description for each domain

\begin{tabular}{|c|c|c|c|}
\hline Domain & Characteristic & Explanation & Categories \\
\hline \multirow[t]{2}{*}{ Criminal case } & Type of offence & $\begin{array}{l}\text { Type of offence } \\
\text { as registered by } \\
\text { the Dutch Public } \\
\text { Prosecution Ser- } \\
\text { vice }\end{array}$ & $\begin{array}{l}\text { Non-violent property offence/violent property offence/violent offence/ } \\
\text { drug offence/sexual offence/traffic offence/vandalism and public } \\
\text { disturbance/other }\end{array}$ \\
\hline & Type of sanction & $\begin{array}{l}\text { Imposed sanction } \\
\text { as registered by } \\
\text { the Dutch Public } \\
\text { Prosecution Ser- } \\
\text { vice }\end{array}$ & $\begin{array}{l}\text { Fine/community service/suspended imprisonment/imprisonment/no } \\
\text { sanction }\end{array}$ \\
\hline
\end{tabular}

* Other types of offences: weapons and ammunition, miscellaneous offences and type of offence unknown.

Table 2 Available data and data source

\begin{tabular}{llllll}
\hline Domain & Source & Organisation & Counting unit & $\begin{array}{l}\text { JS group } \\
n=403(n \%)\end{array}$ & $\begin{array}{l}\text { AS group } \\
n=180(n \%)\end{array}$ \\
\hline Demographic & SSB & Statistics Netherlands & Individuals & $385(95.5)$ & $147(81.7)$ \\
\hline Criminogenic & IRIS & & & & \\
\hline & (OASys) & Dutch Probation Services & Criminal cases & $233(57.8)$ & $34(18.8)$ \\
\hline & (ACL-tool) & Dutch Probation Services & Criminal cases & $167(41.4)$ & $31(17.2)$ \\
\hline Criminal case & RAC-min & Dutch Public Prosecution service & Criminal cases & $403(100)$ & $180(100)$
\end{tabular}

\section{Results}

\subsection{Demographic Characteristics}

Table 3 represents the demographic characteristics of the JS group and the AS group.

No significant differences were found in ethnicity between the groups. The largest ethnic group for young adults in the JS group was Dutch (44.4\%), followed by young adults of Moroccan or Turkish (26.5\%) origin. In the AS group, the percentage of young adults of Dutch origin $(35.4 \%)$ and those of Moroccan or Turkish origin $(36.1 \%)$ was very similar.

In both groups, about one in five young adults was in education at the time of committing the offence $(21.0 \%$ in JS group, $19.0 \%$ in AS group). The JS group is characterised by a significantly lower proportion of young adults who have successfully completed the highest level of education $\left(\chi^{2}(\mathrm{df}=3)=29.5, p<0.05\right)$. Primary school was the most common level of education completed in the JS group (48.1\%), while it was secondary school for the AS group (42.2\%). Regarding the level of education attended, young adults in the JS group had a significant lower level of education attended compared with young adults in the AS group $\left(\chi^{2}(\mathrm{df}=2)=36.1\right.$, $p<0.05)$. In the JS group, the majority of young adults
(56.4\%) have attended some secondary school, while the majority of young adults in the AS group have attended community college or higher $(59.9 \%)$. Furthermore, significant differences between both groups were found regarding socio-economic status $\left(\chi^{2}(\mathrm{df}=3)=16.0\right.$, $p<0.05)$. The socio-economic status with the highest percentage of young adults in the JS group is receiving unemployment benefits $(37.7 \%)$, followed by the socioeconomic status of student (28.8\%). At the time of committing the offence, the socio-economic status with the highest percentage of young adults in the AS group was students $(41.5 \%)$, followed by young adults receiving unemployment benefits $(20.4 \%)$. There was also a significant difference in type of housing between the two groups $\left(\chi^{2}(\mathrm{df}=3)=16.8, p<0.05\right)$. In both groups, at the time of committing the offence, the housing category with the highest percentage of young adults was that of living with parents $(37.4 \%$ in the JS group and $56.5 \%$ in the AS group). However, the percentage of young adults in the category other (e.g. institutionalised or other types of household) was relatively higher in the JS group than in the AS group (20.0\% in JS group and $10.9 \%$ in AS group). 
Table 3 Demographic characteristics of $7 S$ group and AS group

\begin{tabular}{|c|c|c|}
\hline & $\begin{array}{l}\text { JS group } \\
n=385(n \%)\end{array}$ & $\begin{array}{l}\text { AS group } \\
n=147(n \%)\end{array}$ \\
\hline \multicolumn{3}{|l|}{ Ethnicity } \\
\hline Dutch & $171(44.4)$ & $52(35.4)$ \\
\hline Moroccan/Turkish & $102(26.5)$ & $53(36.1)$ \\
\hline Surinam/Dutch Antilles & $37(9.6)$ & $11(7.5)$ \\
\hline Other & 75 (19.5) & $31(21.1)$ \\
\hline \multicolumn{3}{|l|}{ Education } \\
\hline \multicolumn{3}{|l|}{ In education } \\
\hline Yes & $81(21.0)$ & $28(19.0)$ \\
\hline No & $304(79.0)$ & $119(81.0)$ \\
\hline \multicolumn{3}{|c|}{ Highest level of education completed ${ }^{*}$} \\
\hline Community college and higher & $77(20.0)$ & $35(23.8)$ \\
\hline Secondary & $107(27.8)$ & $62(42.2)$ \\
\hline Primary & $185(48.1)$ & $35(23.8)$ \\
\hline Unknown & $16(4.2)$ & $15(10.2)$ \\
\hline \multicolumn{3}{|c|}{ Highest level of education attended ${ }^{*}$} \\
\hline Community college and higher & $152(39.5)$ & $88(59.9)$ \\
\hline Secondary & $217(56.4)$ & $42(28.6)$ \\
\hline Primary/unknown & $16(4.2)$ & $17(11.6)$ \\
\hline \multicolumn{3}{|l|}{ Socio-economic status ${ }^{*}$} \\
\hline Employed & $60(15.6)$ & $29(19.7)$ \\
\hline Unemployment benefits & $145(37.7)$ & $30(20.4)$ \\
\hline Student & $111(28.8)$ & $61(41.5)$ \\
\hline Unemployed/unknown & 69 (17.9) & $27(18.4)$ \\
\hline \multicolumn{3}{|l|}{ Accommodation $^{*}$} \\
\hline With parents & $144(37.4)$ & $83(56.5)$ \\
\hline With one parent & $105(27.3)$ & $30(20.4)$ \\
\hline Independent & 59 (15.3) & $18(12.2)$ \\
\hline Other ${ }^{* *}$ & 77 (20.0) & $16(10.9)$ \\
\hline
\end{tabular}




\subsection{Criminogenic Characteristics}

Table 4 shows the criminogenic characteristics relating to the individual items of the OASys. The JS group is characterised by significantly fewer problems regarding criminal history and (current) offence analysis $\left(\chi^{2}(\mathrm{df}=\right.$ $1)=4.9, p<0.05)$ and financial management and income $\left(\chi^{2}(\mathrm{df}=1)=7.9, p<0.05\right)$. The percentage of young adults with a risk factor regarding criminal history and/or current offence was $47.2 \%$ in the JS group compared with $67.7 \%$ in the AS group. The percentage of young adults with problems regarding financial management and income was $24.0 \%$ in the JS group and $47.0 \%$ in the AS group. On the other hand, the JS group is characterised by significantly more problems regarding lifestyle and associates $\left(\chi^{2}(\mathrm{df}=1)=4.0\right.$, $p<0.05)$ and thinking, behaviour and skills compared with the AS group $\left(\chi^{2}(\mathrm{df}=1)=8.1, p<0.05\right)$. 'Lifestyle and associates' was a risk factor for $47.4 \%$ of the JS group and for $29.4 \%$ of the AS group. In the JS group, $86.7 \%$ of the young adults showed problems regarding thinking, behaviour and skills compared with $67.6 \%$ in the AS group. The JS group also shows high levels of problems regarding education, training and employability $(72.1 \%)$, relationships $(44.2 \%)$ and emotional wellbeing (76.4\%). In the AS group, the Probation Service reported problems regarding education, training and employability (64.7\%), emotional well-being (73.5\%) and thinking, behaviour and skills (67.4\%). In both groups, the majority of offenders scored low to moderate on the total risk score $(51.9 \%$ in the JS group and $53 \%$ in the AS group).
Table 5 provides details of the indications and contraindications for imposing juvenile sanctions based on the ACL screening tool scores. Regarding the indications for juvenile sanctions, there were significant differences between the groups. For $70.7 \%$ of the JS group there was an indication that they have the capacity to instigate behaviour change and would benefit from a juvenile sanction compared with just $35.5 \%$ of the AS group $\left(\chi^{2}(\mathrm{df}=1)=25.7, p<0.05\right)$. Regarding pedagogical possibilities, for $62.3 \%$ of the young adults in the JS group there was an indication that they would benefit from a juvenile sanction, compared with $13.0 \%$ in the $\operatorname{AS}$ group $\left(\chi^{2}(\mathrm{df}=1)=14.2, p<0.05\right)$.

For the majority of young adults in both groups there were no contraindications regarding a juvenile sanction. The JS group and AS group did show significant differences on the criterion psychopathy traits (Fisher's exact test, 1-sided, $p=0.028$ ) and pedagogical impossibilities (Fisher's exact test, 1-sided, $p=0.001$ ). However, psychopathy traits were no contraindication for $98.8 \%$ of the JS group and $90.3 \%$ of the AS group. Pedagogical impossibilities were a contraindication for just $10.2 \%$ of the JS group and for $35.5 \%$ of the AS group. Furthermore, criminal history was a contraindication for just $25.1 \%$ of the JS group and $32.3 \%$ in the AS group. A criminal lifestyle was reported for $9.0 \%$ of the JS group and $19.4 \%$ in the AS group. For $78.4 \%$ of the JS group a juvenile sanction was indicated, while a juvenile sanction was indicated for less than $5.0 \%$ of young adults in the AS group. In the JS group, for $17.4 \%$ of the young adults there was no conclusive advice regarding the type of sanctioning, and in the AS group this was true of $54.8 \%$ of young adults. 
Table $4 \quad$ Criminogenic characteristics of $\mathcal{Z} S$ group and $A S$ group according to $O A S y$ s

\begin{tabular}{|c|c|c|}
\hline OASys item & $\begin{array}{l}\text { JS group } \\
n=233(n \%)\end{array}$ & $\begin{array}{l}\text { AS group } \\
n=34(n \%)\end{array}$ \\
\hline \multicolumn{3}{|c|}{ 1-2 Criminal history and (current) offence analysis ${ }^{*}$} \\
\hline No risk factor & $123(52.8)$ & $11(32.4)$ \\
\hline Risk factor & $110(47.2)$ & $23(67.7)$ \\
\hline \multicolumn{3}{|c|}{3 Housing and living } \\
\hline No risk factor & $194(83.2)$ & $29(85.3)$ \\
\hline Risk factor & $39(16.8)$ & $5(14.7)$ \\
\hline \multicolumn{3}{|c|}{4 Education, training and employability } \\
\hline No risk factor & $65(27.9)$ & $12(35.3)$ \\
\hline Risk factor & $168(72.1)$ & $22(64.7)$ \\
\hline \multicolumn{3}{|c|}{5 Financial management and income ${ }^{*}$} \\
\hline No risk factor & $177(76.0)$ & $18(52.9)$ \\
\hline Risk factor & $56(24.0)$ & $16(47.0)$ \\
\hline \multicolumn{3}{|c|}{6 Relationships with partner, family and relatives } \\
\hline No risk factor & $130(55.8)$ & $20(58.8)$ \\
\hline Risk factor & $103(44.2)$ & $14(41.2)$ \\
\hline \multicolumn{3}{|c|}{7 Lifestyle and associates ${ }^{*}$} \\
\hline No risk factor & $122(52.4)$ & $24(70.6)$ \\
\hline Risk factor & $111(47.4)$ & $10(29.4)$ \\
\hline \multicolumn{3}{|l|}{8 Drug misuse } \\
\hline No risk factor & $146(62.7)$ & $27(79.4)$ \\
\hline Risk factor & $87(37.3)$ & $7(20.6)$ \\
\hline \multicolumn{3}{|c|}{9 Alcohol misuse } \\
\hline No risk factor & $195(83.7)$ & $30(88.2)$ \\
\hline Risk factor & $38(16.3)$ & $<5(-)$ \\
\hline \multicolumn{3}{|c|}{10 Emotional well-being } \\
\hline No risk factor & $55(23.6)$ & $9(26.5)$ \\
\hline Risk factor & $178(76.4)$ & $25(73.5)$ \\
\hline \multicolumn{3}{|c|}{11 Thinking, behaviour and skills ${ }^{*}$} \\
\hline No risk factor & $31(13.3)$ & $11(32.4)$ \\
\hline Risk factor & $202(86.7)$ & $23(67.6)$ \\
\hline \multicolumn{3}{|l|}{12 Attitudes } \\
\hline No risk factor & $142(60.9)$ & $21(61.8)$ \\
\hline Risk factor & $91(39.1)$ & $13(26.5)$ \\
\hline
\end{tabular}


Table 4 Criminogenic characteristics of $7 S$ group and $A S$ group according to OASys

\begin{tabular}{lll}
\hline OASys item & $\begin{array}{l}\text { JS group } \\
n=233(n \%)\end{array}$ & $\begin{array}{l}\text { AS group } \\
n=34(n \%)\end{array}$ \\
\hline Total risk assessment & & $18(53.0)$ \\
\hline Low-moderate & $121(51.9)$ & $8(23.5)$ \\
\hline High-very high & $72(30.9)$ & $8(23.5)$ \\
\hline No total risk assessment & $40(17.2)$ & \\
& &
\end{tabular}

Table 5 Criminogenic characteristics according to adolescent criminal lam screening tool

\begin{tabular}{|c|c|c|}
\hline $\begin{array}{l}\text { Indications and contraindication for sentencing with juvenile } \\
\text { sanctions }\end{array}$ & $\begin{array}{l}\text { JS group } \\
n=167(n \%)\end{array}$ & $\begin{array}{l}\text { AS group } \\
n=31(n \%)\end{array}$ \\
\hline \multicolumn{3}{|l|}{1 Capacity to instigate behaviour change* } \\
\hline Indication & $118(70.6)$ & $11(36.5)$ \\
\hline No indication & $49(29.3)$ & $20(64.5)$ \\
\hline \multicolumn{3}{|l|}{2 Pedagogical possibilities* } \\
\hline Indication & $104(62.3)$ & $<5(-)$ \\
\hline No indication & $63(37.7)$ & $27(87.0)$ \\
\hline \multicolumn{3}{|l|}{3 Criminal history } \\
\hline Contraindication & $42(25.1)$ & $10(32.3)$ \\
\hline No contraindication & $125(74.9)$ & $21(67.7)$ \\
\hline \multicolumn{3}{|l|}{4 Criminal lifestyle } \\
\hline Contraindication & $15(9.0)$ & $6(19.4)$ \\
\hline No contraindication & $152(91.0)$ & $25(80.6)$ \\
\hline \multicolumn{3}{|l|}{5 Psychopathy traits* } \\
\hline Contraindication & $<5(-)$ & $<5(-)$ \\
\hline No contraindication & $165(98.8)$ & $28(90.3)$ \\
\hline \multicolumn{3}{|l|}{6 Pedagogical impossibilities ${ }^{*}$} \\
\hline Contraindication & $17(10.2)$ & $11(35.5)$ \\
\hline No contraindication & $150(89.8)$ & $20(64.5)$ \\
\hline \multicolumn{3}{|l|}{ Conclusion } \\
\hline Indication & $131(78.4)$ & $<5(-)$ \\
\hline Contraindication & $7(4.2)$ & $8(25.8)$ \\
\hline No conclusive advice & $29(17.4)$ & $17(54.8)$ \\
\hline
\end{tabular}

${ }^{*} \mathrm{p}<0.05$. 


\begin{tabular}{|c|c|c|}
\hline & $\begin{array}{l}\text { JS group } \\
n=403(n \%)\end{array}$ & $\begin{array}{l}\text { AS group } \\
n=180(n \%)\end{array}$ \\
\hline Mean age (SD) & $18.8(1.1)$ & $19.3(1.4)$ \\
\hline \multicolumn{3}{|l|}{ Age $^{*}$} \\
\hline 18 & $211(52.4)$ & $76(42.2)$ \\
\hline 19 & $100(24.8)$ & $40(22.2)$ \\
\hline 20 & $54(13.4)$ & 19 (10.6) \\
\hline 21 & $25(6.2)$ & $30(16.7)$ \\
\hline 22 & $13(3.2)$ & $15(8.3)$ \\
\hline \multicolumn{3}{|l|}{ Type of offence } \\
\hline Non-violent property offence & $152(37.7)$ & $75(41.7)$ \\
\hline Violent property offence* $^{*}$ & $88(21.8)$ & $<5(-)$ \\
\hline Violent offence & $109(27.0)$ & $36(20.0)$ \\
\hline Drug offence & $15(3.7)$ & $12(6.7)$ \\
\hline Sexual offence & $8(2.0)$ & $<5(-)$ \\
\hline Traffic offence $^{*}$ & $<5(-)$ & $10(5.6)$ \\
\hline Vandalism and public disturbance & $52(12.9)$ & $22(12.2)$ \\
\hline Other ${ }^{* A}$ & $17(4.2)$ & $20(11.1)$ \\
\hline \multicolumn{3}{|l|}{ Type of sanction } \\
\hline Fine $^{*}$ & $<5(-)$ & $27(15.0)$ \\
\hline Community service* $^{*}$ & $81(20.1)$ & $52(28.9)$ \\
\hline Suspended detention & $71(17.6)$ & $32(17.8)$ \\
\hline Mandatory detention* & 209 (51.9) & $55(30.6)$ \\
\hline Other & $38(9.4)$ & $14(7.8)$ \\
\hline
\end{tabular}

${ }^{*} \mathrm{p}<0.05$.

A Other: weapons and ammunition, miscellaneous offences and type of offence is unknown.

\subsection{Criminal Case Characteristics}

Table 6 presents criminal case characteristics for the JS group and the AS group. Regarding type of offence and type of sanction, significant differences were found between both groups. The JS group committed significantly more violent property offences $\left(\chi^{2}(\mathrm{df}=1)=\right.$ $36.0, p<0.05)$, fewer traffic offences $\left(\chi^{2}(\mathrm{df}=1)=15.8\right.$, $p<0.05)$ and fewer other type of offences $\left(\chi^{2}(\mathrm{df}=1)=\right.$ $9.9, p<0.05)$ compared with the AS group. The most frequently committed offence in both groups was a nonviolent property offence $(37.7 \%$ in JS group and $41.7 \%$ in $\mathrm{AS}$ group), followed by a violent offence $(27.0 \%$ in the JS group and $20.0 \%$ in the AS group). In the JS group more than one in five $(21.8 \%)$ of the committed offences was a violent property offence, while less than five percent of the AS group committed a violent property offence. In the JS group, less than five of the crim- inal cases $(<1.2 \%)$ concerned a traffic offence, while in the AS group $6.7 \%$ of the criminal cases concerned a traffic offence.

Regarding type of sanction, the JS group received significantly fewer fines $\left(\chi^{2}(\mathrm{df}=1)=48.5, p<0.05\right)$ and more mandatory detentions $\left(\chi^{2}(\mathrm{df}=1)=22.8, p<0.05\right)$ compared with the AS group. Mandatory detention $(51.9 \%)$ was the most frequently applied sanction in the JS group, followed by community service (20.1\%) and suspended detention (17.6\%). A fine was the least frequently imposed sanction $(<1.2 \%)$. In the AS group, the most frequently applied sanction was also mandatory detention $(30.6 \%)$, followed by community service $(28.9 \%)$ and a fine $(15.0 \%)$. 


\section{Discussion}

The aim of this study was to gain insight into the demographic, criminogenic and criminal case characteristics of 18-22-year-olds sentenced with juvenile sanctions in the first year after the introduction of ACL. Two important results were found. First, young adults who were sentenced with juvenile sanctions in this period are characterised by problems across different domains. Second, indications for juvenile sanctions were a deciding factor during the selection process of young adults who are eligible for sanctioning according to juvenile criminal law.

\subsection{JS group: Young Adults with Problems} Across Different Domains

On the basis of the description of young adults eligible for juvenile sanctions, according to the Explanatory Memorandum, we expected this group of young adults to be a heterogeneous group with problems across different domains. Although no differences were found between the JS group and the AS group in the percentage of young adults who were in education at the time of committing the offence, there were differences between both groups in the level of education. Young adults in the JS group had relatively more often a lower level of completed education and a lower level of education attended compared with young adults in the AS group. In addition, young adults in the JS group were significantly more often in receipt of unemployment benefits, while young adults in the AS group were more often students. Furthermore, young adults in the JS group were more likely to be living in an institution or other type of undefined housing. On the contrary, young adults in the AS group were more likely to be living with their parents.

A possible explanation for these findings may be found in the fact that young adults in the JS group were more likely to demonstrate problems regarding thinking, behaviour and skills (e.g. cognitive deficits, a lack of social skills, impulse control problems and/or a lack of empathy), as well as problems regarding their emotional well-being. This assumption is supported by the fact that young adults in the JS group committed more violent property offences. This may indicate a lack of impulse control and problems with aggression regulation. ${ }^{36}$ This may further explain the relatively high percentage of mandatory detentions in the JS group, as these young adults commit more serious offences compared with young adults in the AS group. This is in line with the Explanatory Memorandum, in which it is stated that juvenile sanctions are intended for young adult offenders of offences that are more serious and therefore more likely to lead to pre-trial detention. ${ }^{37}$

It is plausible that the characteristics of young adults sentenced with juvenile sanctions may hamper these

36. Prior et al., above n. 13; Monahan et al. (2009), above n. 9; Bonnie and Scott, above n. 7.

37. Parliamentary Documents II, 2012/13, 33498, no. 3, at 6, 22 young adults from attending and completing a higher level of education, from having a job and from living with their parents. These findings correspond to studies into background characteristics of young adults in judicial youth institutions in the Netherlands. ${ }^{38}$ Young adults in these previous studies demonstrated behavioural problems (e.g. impulsivity, hyperactivity), psychological problems, alcohol and/or drug abuse. Furthermore, the majority of young adults in these studies had a problematic family background (e.g. domestic violence and abuse), and they experienced problems regarding financial management (e.g. debts). ${ }^{39}$

The risk-need-responsivity model (RNR) for assessment and treatment of offenders states that individuals can desist from crime if they receive an appropriate level of treatment that is proportional to their risk of reoffending. ${ }^{40}$ In the RNR a distinction is made between static (immutable risk factors) and dynamic risk factors (criminogenic needs) that are related to criminal behaviour, such as antisocial personality patterns (e.g. impulsivity and aggressive behaviour), substance abuse, school or work (poor school/work performance) and family relationships (e.g. inappropriate parental monitoring and disciplining). ${ }^{41}$ Although both groups scored low to moderate on the total risk score of the OASys, the JS group showed more often dynamic risk factors (e.g. problems regarding thinking, behaviour and skills and emotional well-being), and the AS group showed more often static risk factors (e.g. criminal history). These results seem to indicate that, because of the dynamic risk factors, it is thought that young adults in the JS group may benefit more from the developmental approach of juvenile sanctions.

\subsection{Indications for Juvenile Sanctions Are Decisive}

Pre-trial forensic advice concerning the offender's personal characteristics was emphasised with the introduction of ACL. Probation officers can use an ACL screening tool to determine which young adults are eligible for sentencing with juvenile sanctions. According to the probation officers, the majority of young adults in the JS group showed indications (e.g. capacity to instigate behaviour change and pedagogical possibilities) that made them eligible for a juvenile sanction. On the contrary, the majority of both groups showed no contraindications (e.g. criminal history, criminal lifestyle, psychopathy traits and pedagogical impossibilities) for juvenile sanctions. These results suggest that, regardless of multiple problems, from the probation officers' point of

38. L. Boendermaker et al., Zorgaanbod voor 18- tot 23-jarigen in justitiële jeugdinrichtingen (University of Groningen, 2014).

39. B.O. Vogelvang et al., Prevalentie van criminogene factoren bij mannelijke gedetineerden in Nederland (Adviesbureau Van Montfoort/ WODC, 2003); S. Noordhuizen and G. Weijters, Derde meting van de nazorg ex-gedetineerden (WODC, 2012).

40. D.A. Andrews, J. Bonta and J.S. Wormith, 'The Risk-Need-Responsivity (RNR) Model. Does Adding the Good Lives Model Contribute to Effective Crime Prevention?', 38 Criminal Justice and Behavior 735 (2011); Bonta and Andrews, above n. 33

41. Bonta and Andrews, above n. 33 
view, young adults who were sentenced with juvenile sanctions are likely to benefit more from the pedagogically oriented juvenile criminal law. Furthermore, demographic characteristics show that more young adults from the AS group are living with their parent(s), while living with parents is considered an indication for sentencing with juvenile sanctions. A possible explanation for this finding may be found in the fact that ACL is intended for a diverse target group and results show that the JS group is characterised by problems across different domains. It is likely that these characteristics contribute to the fact that young adults of the JS group do live less often with their parents, but are instead institutionalised or in another type of household. In addition, results indicate that vulnerable young adults were sentenced with juvenile sanctions. This result may indicate that professionals see vulnerability rather than pedagogical possibilities as an indication for juvenile sanctions. It is therefore important, in line with the RNR, to consider the dynamic criminogenic needs of an individual when selecting an intervention..$^{42}$ This is also in line with the Explanatory Memorandum, in which it is stated that juvenile criminal law, with its pedagogical character and focus on resocialisation, offers a more tailored approach to sentencing compared with adult criminal law. ${ }^{43}$

\subsection{Limitations}

This is the first study since the introduction of ACL in which the characteristics of young adults who were sentenced with juvenile sanctions in the Netherlands were examined. However, this study has three limitations that should be considered when interpreting the results. First, the AS group consists of a sample stratified by age and an oversampling of 21- and 22-year-old offenders. This resulted in an over-representation of 18 -year-olds and a lower percentage of 21- and 22-year-olds in the AS group compared with the population of young adults sentenced according to adult criminal law. In addition, the JS group and AS group differ significantly in age. Second, the study sample was selected on the basis of criminal cases that were settled by district courts. During the pre-trial phase, there are several dropout moments in the selection of young adults eligible for juvenile sanctions. Therefore, the results of this study are limited to young adult offenders that were dealt with by the judge. And third, data used in this study were registered in the context of the criminal trial, and information was not available for many of the criminal cases. Despite the fact that pre-trial forensic advice is emphasised in ACL, one in five criminal cases in the JS group and even fewer cases in the AS group lacked this information.

\subsection{Concluding Remarks}

In conclusion, as expected, young adults sentenced with juvenile sanctions showed relatively more characteristics indicative of problems across different domains. Furthermore, they committed more offences of a serious nature compared with young adults sentenced with adult sanctions. At the same time, it seems that these young adults are more likely to have the capacity to instigate behaviour change compared with other young adult offenders. The main focus of ACL is on the special treatment of young adult offenders in order to increase resocialisation and reduce recidivism. To benefit from this special treatment, it is important to select young adults for whom juvenile sanctions may offer opportunities to change their criminal behaviour. In ACL, special attention is given to young adult offenders with immature emotional, social, moral and/or intellectual development. Owing to their immaturity, these young adults are more likely to benefit from the developmental approach of juvenile sanctions. However, the concept of maturity remains elusive and is therefore difficult to assess. Although young adults sentenced with juvenile sanctions seem to indicate some level of immaturity (e.g. impulsivity, inability to oversee long-term consequences, sensitivity to peer influences) and although emotional or practical support by adults and continuing school attendance is desirable, it remains unknown whether and to what extent these young adults are immature. While the findings of this study provide support for the special treatment of young adult offenders in criminal law, as intended by ACL, further research is needed to show whether the special treatment of young adults is effective in increasing resocialisation and reducing recidivism. 